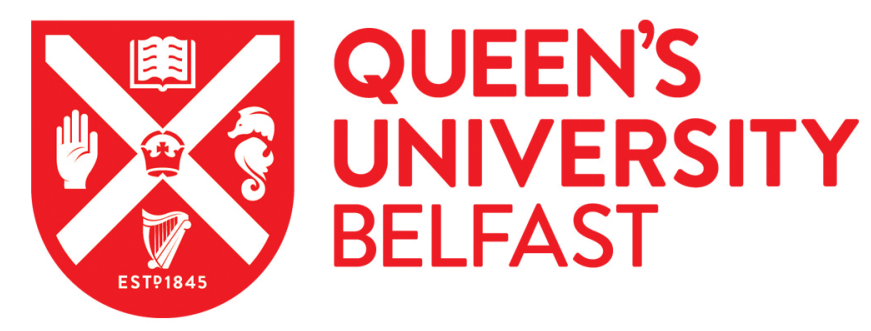

\title{
Understanding International Product Strategy in Multinational Corporations through New Product Development Approaches and
} Evolution

Liu, Y., \& Shi, Y. (2017). Understanding International Product Strategy in Multinational Corporations through New Product Development Approaches and Evolution. International Journal of Innovation Management, 21(7), [1750057]. https://doi.org/10.1142/S1363919617500578

Published in:

International Journal of Innovation Management

Document Version:

Peer reviewed version

Queen's University Belfast - Research Portal:

Link to publication record in Queen's University Belfast Research Portal

Publisher rights

(c) 2017 World Scientific Publishing Company.

This work is made available online in accordance with the publisher's policies. Please refer to any applicable terms of use of the publisher.

\section{General rights}

Copyright for the publications made accessible via the Queen's University Belfast Research Portal is retained by the author(s) and / or other copyright owners and it is a condition of accessing these publications that users recognise and abide by the legal requirements associated with these rights.

\section{Take down policy}

The Research Portal is Queen's institutional repository that provides access to Queen's research output. Every effort has been made to ensure that content in the Research Portal does not infringe any person's rights, or applicable UK laws. If you discover content in the

Research Portal that you believe breaches copyright or violates any law, please contact openaccess@qub.ac.uk. 


\title{
Understanding International Product Strategy in Multinational \\ Corporations through New Product Development Approaches and \\ Evolution
}

\begin{abstract}
International product strategy regarding global standardisation and local adaptation is one of the challenges faced by multinational corporations (MNCs). Studies in this area have tested the antecedents and consequences of standardisation/adaptation, but lack a new product development (NPD) perspective. In this study, we explore how product standardisation/adaptation is determined in the NPD context. Through a qualitative case study of four MNCs, we found three NPD approaches: multi-local, adaptation-based and platform-based. We analysed the advantages and challenges of each approach. In addition, we reveal how the factors (development of information and communication technology, competition pressure, brand awareness and technical capability) could influence the choice of a certain NPD approach. We draw implications on the paths to ensuring full leveraging of the benefits of a platform-based approach.
\end{abstract}

Keywords: Multinational corporations; global standardisation; local adaptation; new product development; platforms. 


\section{Introduction}

Multinational corporations (MNCs) are believed to be at the forefront of organisational and managerial innovations (Bélanger, Berggren, Björkman, \& Köhler, 1999), as they face the challenges of global competition and the management of worldwide activities resulting in greater complexity than that faced by domestic firms (Bartlett \& Ghoshal, 2000, Yip, 2003). One of the challenges in MNCs is the development of international product strategy regarding global standardisation and local adaptation (Katsikeas, Samiee, \& Theodosiou, 2006, Kotabe, 1990). In many industries, there are still different market requirements across countries in terms of customer tastes, local conditions and regulations (Gooderham, 2012, Rugman \& Hodgetts, 2001). MNCs need to identify commonalities and differences in requirements and offer products accordingly (Kotler, 1986, Levitt, 1983).

The strategic importance of new product development (NPD) lies in the cross-functional nature of this task (Wheelwright \& Clark, 1992). Studies have shown interactions between product strategy and NPD activities. Many product-related decisions are actually made in the NPD process (Cooper, 1994, Schmidt \& Calantone, 2002, Ulrich \& Eppinger, 2012). Therefore, it is essential to understand product strategy in the context of NPD.

Whereas previous studies have tested the antecedents and consequences of international product strategy (Calantone, Kim, Schmidt, \& Cavusgil, 2006, Cavusgil \& Zou, 1994, Katsikeas, Samiee, \& Theodosiou, 2006), very few studies have explored international product strategy from an NPD perspective. However, NPD activities could significantly influence the product form. For example, when some requirements are not considered early on in an NPD project, significant redesign is needed afterwards (Gunzenhauser \& Bongulielmi, 2008). Such NPD activities are likely to affect the competitiveness of MNCs and therefore it is important to understand how MNCs choose an NPD approach under certain conditions. For NPD approaches in MNCs, we focus on the way of organising NPD activities that affects global standardisation and local adaptation of products. 
This study aims to contribute to the understanding of international product strategy and NPD in several ways. To be specific, we identify several NPD approaches in MNCs and explain their advantages and challenges. We show how product standardisation/adaptation is determined in these NPD approaches. In addition, we reveal how certain factors could influence the adoption of a certain NPD approach.

This paper is structured as follows. In the next section, Theoretical Background, relevant studies related to international product strategy and NPD are analysed and research gaps are identified. In the section of Research Methods, the research design is presented including the choice of case companies, data collection and data analysis. In the Case Studies section, we present a detailed description of cases. In the Findings section, we show key findings of three NPD approaches and relevant influencing factors across four MNCs. In the Discussion section, we highlight the theoretical contributions and practical implications of this study, and explore the research limitations and future research avenues.

\section{Theoretical Background}

\section{International Product Strategy in MNCs}

Global standardisation and local adaptation have been the subject of discussion for a long time. With standardisation, firms can achieve economies of scale and therefore offer high quality products at a low price (Levitt, 1983). With adaptation, products may be more appealing to customers in terms of the desired functions or aesthetics (Kotler, 1986). Cooper and Kleinschmidt (1985) suggest that international product strategy can be viewed on a continuum and firms position themselves somewhere between standardisation and adaptation. It is measured as the level of product or component sharing across countries (Calantone, Cavusgil, Schmidt, \& Shin, 2004, Zou \& Cavusgil, 2002).

Empirical studies have examined the antecedents and consequences of global 
standardisation and local adaptation. Such studies have explored product strategy either directly or as an element of marketing strategy. Regarding antecedents, Samiee and Roth (1992) argue that the rate of technological change and the frequency with which competitors change products will influence the emphasis on global standardisation in a firm. Katsikeas, Samiee, and Theodosiou (2006) find that the degree of standardisation is related to the similarity between markets in six respects: regulatory environment, technological intensity and velocity, customs and traditions, customer characteristics, the stage of the product in its life cycle and competitive intensity. Zou and Cavusgil (2002) find international experience, global orientation and external globalising conditions to be antecedents of global marketing standardisation. These studies have been undertaken for MNCs.

In terms of studies on export firms, Cavusgil, Zou, and Naidu (1993) tested the influence of three factors on the degree of product adaptation in export ventures: company characteristics (a firm's international experience, export sales goal and entry scope), product/industry characteristics (technological orientation of the industry, product uniqueness, cultural specificity of the product and type of product) and export market characteristics (similarity of legal regulations, competitiveness of the export market and product familiarity of export customers). Cavusgil and Zou (1994) identified six significant antecedents in a study of export marketing strategy: international competence, product uniqueness, the cultural specificity of the product, export market competitiveness, a firm's experience with the product and the technological orientation of the industry. Calantone, Cavusgil, Schmidt, and Shin (2004) conducted research on the product adaptation of US and South Korean export firms. They identified three antecedents of product adaptation: similarity in the legal environment of the home and export markets, relevant experience of the business unit in international marketing, responsive marketing organisation and customer-orientated practices. Calantone, Kim, Schmidt, and Cavusgil (2006) then identified another three antecedents: export dependence, industry adaptation and market similarity.

Studies have tested the consequences of standardisation/adaptation, including strategic and financial performance. Zou and Cavusgil (2002) show that global 
standardisation has a positive relationship with the strategic and financial performance of MNCs. In contrast, Samiee and Roth (1992) study reveals that the emphasis on global marketing standardisation in MNCs is not significantly related to financial performance. Some studies draw the conclusion that the degree of product adaptation is positively related to export performance for export firms (Calantone, Cavusgil, Schmidt, \& Shin, 2004, Cavusgil \& Zou, 1994, Leonidou, Katsikeas, \& Samiee, 2002).

Overall, prior studies suggest that a standardisation/adaptation strategy is contingent on many factors such as industry and company characteristics, and there is no single optimal strategic position for all firms (Schmid \& Kotulla, 2011). In addition, choosing the right strategy is essential for the superior performance of the firm (Katsikeas, Samiee, \& Theodosiou, 2006).

\section{Global Product Development}

Previous studies on global product development have predominantly examined cross-border collaboration and there are several streams of research. One stream concerns the behavioural environment, defined as the firm's organisational culture and management commitment (De Brentani \& Kleinschmidt, 2004). Studies have tested the direct (De Brentani \& Kleinschmidt, 2004, Salomo, Kleinschmidt, \& de Brentani, 2010) and indirect (De Brentani, Kleinschmidt, \& Salomo, 2010, Kleinschmidt, de Brentani, \& Salomo, 2007) relationships between the behavioural environment (innovation/globalisation culture, resource commitment and top management involvement) and global NPD performance, emphasising the importance of the behavioural environment in facilitating cross-border collaboration.

Also, there are studies exploring the challenges of global NPD teams. By integrating globally dispersed members into a global NPD team, MNCs could leverage talents worldwide and increase cultural sensitivity (Eppinger \& Chitkara, 2006, Graber, 1996, Salomo, Kleinschmidt, \& de Brentani, 2010). However, as global NPD team members are culturally diverse, they are likely to lack shared beliefs, 
experiences and expectations, which diminishes trust (Barczak \& McDonough, 2003, Bierly III, Stark, \& Kessler, 2009, McDonough III, Kahn, \& Barczak, 2001). Team members may even encounter conflicts as a result (Tavcar, Zavbi, Verlinden, \& Duhovnik, 2005). Bierly III, Stark, and Kessler (2009) argue that increasing the frequency of face-to-face communication is one approach to enhancing trust, but the team members also need to overcome the communication barrier caused by cultural differences (Hansen \& Ahmed-Kristensen, 2011, Jarvenpaa \& Leidner, 1999).

Other studies have examined knowledge management in global NPD. MNCs have the advantage of acquiring local knowledge. However, to reap the benefits, dispersed knowledge needs to be integrated, and how to integrate knowledge in NPD is a challenge for MNCs (Söderquist, 2006). Subramaniam (2006) finds that the cross-national collaboration climate is the key to integrating knowledge globally. Subramaniam and Venkatraman (2001) argue that increased frequency of communication in project teams is effective for processing tacit overseas information. Tavcar, Zavbi, Verlinden, and Duhovnik (2005) find that there is an optimum level of communication which fosters creativity, while too much or too little communication reduces creativity.

The development of information and communication technology (ICT) has changed the NPD approach in many aspects. One important aspect is promoting cross-border collaborations (Chang, 2006, Howells, 1995). ICT tools are useful for global knowledge integration, especially when knowledge is not highly tacit. For virtual global teams, videoconferencing makes intense communication possible and when videoconferencing is combined with face-to-face meetings, communication in NPD can be highly effective while maintaining low travel costs (Tavcar, Zavbi, Verlinden, \& Duhovnik, 2005). Kleinschmidt, de Brentani, and Salomo (2010) argue that ICT infrastructure can increase the firm's ability to access, integrate and transform widely dispersed information and skills. They empirically tested the positive relationship between ICT infrastructure and NPD performance. In addition, Nambisan (2003) finds that ICT could influence process management (making the process more comprehensive or flexible) and project management (better resource 
monitoring and control) of NPD. Ozer (2000) finds that ICT can influence the speed of NPD.

\section{NPD Perspective of Product Strategy}

NPD is an important source of a firm's competitiveness (Bessant \& Francis, 1997, Eslami \& Lakemond, 2016, Millson \& Kim, 2015). It is a complex task calling for collaboration across the functions of R\&D, marketing, manufacturing, finance, etc. (Griffin \& Hauser, 1993, Wheelwright \& Clark, 1992). In practice, product strategy is formulated and adjusted in the NPD context, with many product-related decisions being made throughout the NPD process (Luchs \& Swan, 2011, Muffatto, 1999, Shibata \& Kodama, 2015). For example, in the idea generation phase, firms need to identify business opportunities and conduct business case analysis, through which the firms will determine what products to develop (Kim \& Wilemon, 2002, Ulrich \& Eppinger, 2012, Verworn, 2006). Another example is the Stage-Gate ${ }^{\circledR}$ process, through which firms review an NPD project at each gate meeting (Cooper, 1994, Hart, Jan Hultink, Tzokas, \& Commandeur, 2003, Schmidt \& Calantone, 2002, Tzokas, Hultink, \& Hart, 2004). Based on the available information at that time point, the project can pass the gate or be killed off. Therefore, discussions concerning product strategy should not be separated from the NPD context.

More studies have confirmed this NPD perspective on product strategy. Bloch (1995) indicates that in the product design process, the requirements of consumers and distributors, regulations, production equipment, the marketing programme and designers jointly influence the form of products. Hauser, Tellis, and Griffin (2006) suggest that firms need to choose the right technology to develop in the early phase of NPD. Seidel (2007) shows how initial product concepts are changed in the NPD process when new technical or market information becomes available. Ulrich (1995) shows how product modularity is realised in NPD. Moorman and Miner (1998) define the term 'improvisation' and suggest that formulating strategies and performing activities could happen simultaneously in NPD. Trappey, Trappey, Tzu-An, and 
Jen-Yau (2009) suggest firms strive to optimise product portfolios with limited NPD resources.

Studies on international product strategy have predominantly explored the antecedents and consequences of standardisation/adaptation. However, very few studies have addressed the issue of international product strategy from an NPD perspective, that is, how standardisation/adaptation decisions are made in the NPD context. An NPD perspective is needed because various issues of NPD (e.g. how NPD activities are organised) are likely to interact with standardisation/adaptation. We also know less about how different NPD approaches in MNCs can influence the standardisation/adaptation of product form, and why an approach is chosen over others. Studies on global NPD have tended to focus on cross-border collaboration and knowledge management, falling short of discussions on standardisation/adaptation issues. This study aims to contribute to the understanding of international product strategy and NPD in this regard.

\section{Research Methods}

In this research, we chose the qualitative case study method to explore product standardisation/adaptation in the NPD context. A case study is suitable when the boundaries between concepts and the context are not clear (Yin, 2009). In this study, we argue that the NPD context is especially important for understanding international product strategy. Case study research is also appropriate for explorative study (Yin, 2009), as in this case we had limited knowledge regarding the NPD perspective in relation to international product strategy. A multiple-case design allows us to make comparisons across cases to broaden our insights (Eisenhardt, 1989, Eisenhardt \& Graebner, 2007).

When choosing case companies, we adopted a diverse sampling approach (Eisenhardt, 1989). This approach is widely used, because firms with different settings could broaden the insights generated from the case study (Andriopoulos \& Lewis, 2009, Bohnsack, Pinkse, \& Kolk, 2014, Lawrence \& Dover, 2015). Also, 
replication can be realised through studying firms with different backgrounds (Yin, 2009). In this research, we chose four automotive MNCs headquartered in different countries as case companies (see Table 1). We focused on their NPD approaches in the global context, how the NPD approaches evolved over time and their influence on product forms (standardisation/adaptation). We intentionally chose MNCs which adopted different NPD approaches for standardisation/adaptation at the time of the study or in history. To collect data, we interviewed R\&D managers and engineers in the case companies. In total, we conducted 12 semi-structured interviews for all case firms. Each interview lasted for 1-1.5 hours. The interview protocol is shown in Appendix. Also, we collected secondary data (mainly press releases and news articles) from the internet to complement our understanding of the case companies.

Table 1 Summary of Cases

\begin{tabular}{|l|l|l|l|}
\hline Case & Headquarters & Sales Volume* & Market \\
\hline Case 1 & USA & 155 billion & Global \\
\hline Case 2 & Japan & 101 billion & Global \\
\hline Case 3 & China & 3 billion & Mainly developing countries \\
\hline Case 4 & China & 91 billion & Global except the USA \\
\hline
\end{tabular}

* Sales data in 2013, converted to US dollars according to the average exchange rate in 2013

This study focuses on the category of passenger cars (i.e. not including commercial vehicles). Based on our study, we found that while the same sizes (such as C-segment) are needed globally (except A-segment), market requirements differ evidently across countries and regions. For example, American people need greater power whereas European people require higher efficiency of engines. Another example is the hardness of the suspension due to different road conditions. Also, the crash test standards are different region by region.

We conducted data analysis in the way suggested by Yin (2009). First, we 
compiled information and wrote case reports for each company including: the background of the company, the companies' historical NPD approach, evolution in the NPD approach and influencing factors. At this stage, we conducted within-case analysis. We then compared the findings across cases to explore common patterns and variations. Through this comparison, we aimed to explain the findings in the four cases and deepen our understanding. For example, the Chinese MNCs (Cases 3 and 4) adopted different NPD approaches from developed country MNCs (Cases 1 and 2). We tried to find explanations for such variation from different aspects. In addition, we found that even for Chinese MNCs (Cases 3 and 4), the NPD approaches could be somewhat different and certain factors could influence that. The findings in the four cases allowed us to build a theory explaining the choice of NPD approaches in MNCs.

\section{Case Studies}

\section{Case 1}

The company in Case 1 is headquartered in the US. It has R\&D centres in North America (the US), Europe (Germany) and Asia Pacific (Australia). Historically, each $R \& D$ centre developed cars independently for the regional market. In NPD, the cars were tailored to regional requirements (e.g. styling) and regulations (e.g. crash tests). This was actually a natural outcome as this company entered Europe and the Asia Pacific region through acquisitions. The acquired companies had NPD capability and strong brands. Case 1 largely maintained the existing operations at that time. In an era in which ICT was less developed and used, this global NPD approach was a reasonable choice as $R \& D$ centres were closer to the market so they understood what the customers really wanted. However, under this approach it was very difficult to share components globally as the $R \& D$ centres were too independent in terms of power, processes and design habits. The firm suffered from duplication in product design, which made it less and less competitive over time due to high costs.

Starting from the late 1990s, the company changed its NPD approach. Global 
platforms (referred to as architectures in the company) were created based on car categories: A, B, C, CD and D. With the platform approach, the international product strategy focused on "simplifying the platforms and diversifying the products". When developing the global platform, the requirements of different regions and feedback from those regions were taken into consideration from the beginning. This became easier with the use of ICT tools. To facilitate the change, the firm shifted the organisational structure of $\mathrm{R} \& \mathrm{D}$. For example, the German centre was nominated as the lead centre for the B-car development to facilitate collaboration across regions. Other R\&D centres were controlled by the German centre for NPD. Under this approach, products were still differentiated to accommodate differences in local requirements, but significant parts (defined as the platforms) were shared globally. The level of sharing could vary case by case. In most cases only the chassis was shared; in other cases, the car body was also shared, but with modified bonnets, bumpers and doors.

With the new NPD approach, for each car the cost was lower due to shared parts, which gave the company a cost advantage. Also, the company was able to develop more car models to attract different customer groups.

\section{Case 2}

Case 2 is a Japanese automotive company. Historically, its NPD capability was concentrated in Japan. The traditional approach was that the cars were developed based on Japanese requirements only, as communication across borders was not very convenient at that time. Then, after their launch on the Japanese market, some of the cars were introduced in other countries. These cars were then adapted in local subsidiaries, mainly to take account of local regulations, production facilities and suppliers. While this strategy was intended to minimise costs, economies of scale were never fully leveraged as such local adaptation needed considerable redesign work. The costs were still relatively low as the basic design was the same globally. However, the car, although cheaper, did not fully meet local customer requirements in 
terms of dimensions and aesthetics.

In the late 2000s, as the company found it was less and less competitive in the global market, it moved away from the traditional NPD approach. Different local requirements were taken into consideration early on in NPD projects, so that the developed cars could appeal to more customers in different countries. The NPD team separated the global and local parts during the project and made different versions of cars accordingly for different markets. To achieve this, the firm created a culture of collaboration. All the local subsidiaries were highly involved in the NPD process through providing feedback. ICT tools made this task easier. The firm also worked to abandon the old mindset of central authority and be more accommodating to local subsidiaries’ views on car design.

With the new global NPD approach, the company attained better economies of scale. Significant numbers of parts were shared globally, not needing redesign. Also, the cars were more suited to customers' tastes in different markets.

\section{Case 3}

Case 3 is a Chinese automotive company. Under the government's "going-out" strategy, it sought to internationalise operations and sell its cars aboard in the early 2000s. In terms of an NPD approach, it followed the same approach as Case 2, developing cars for Chinese customers only and then introducing some cars in other countries with adaptations.

In the mid-2000s, this company attempted to develop a global car for different markets, but the project ultimately failed. In the NPD process, the engineering team found it very difficult to pass the regulations in developed countries. It finally managed to comply with the regulations with many revisions, but the cost was very high. What was worse, the product was not at all attractive in developed countries, partly because few people recognised the brand. It was not even attractive in China as it deviated from the low-cost position of the firm.

After the failure of this project, the company stayed focused on developing 
countries which did not have very high standards. The customers in developing countries were more price sensitive, making it easier for the company to sell its cars. Also, the company reverted to its original NPD approach to focus on Chinese requirements in projects as the NPD team could not determine the volume of potential car sales in a certain country. This was also because the company was more established in China and the volume was more likely to be sufficient to justify such an investment. Then, after a product was launched in China, the local marketing team promoted it in the local market and then evaluated the local market volume. If there was sufficient volume, the company would introduce that car with adaptations.

\section{Case 4}

Case 4 is a Chinese automotive company, too. Unlike Case 3, in the mid-2000s it obtained technologies, brands and distribution channels through the acquisition of a Western firm. This provided an opportunity for the firm to expand its overseas market. Although it was able to meet the standards in developed countries with the acquired technologies, the quality of the car and brand awareness were still much lower than the industry leaders. Under such conditions, the company largely followed the same approach as Case 2, focusing on Chinese requirements in NPD projects and then introducing the cars in sufficient volume to other countries with adaptations.

The company was seeking the opportunity for a global car and it developed and launched one for the global market (except in the USA) in the late 2000s. For this car, the requirements of all markets were taken into consideration early on in the NPD project. Compared to Case 3, this car was not a total failure. However, the overseas sales were still below the target. The company chose to continue the global car approach for the next generation of this model and included a diesel engine option to stimulate sales. It remained to be seen if this model could reach the target sales volume.

For other cars, the company still defined them as Chinese cars in NPD projects although the engineering team started to consider a few requirements (such as 
left-wheel and right-wheel drive) in other countries for the convenience of later modification. As the overseas market volume was not certain in the early stage of NPD, the firm could hardly benefit from developing global cars. In comparison, the market volume was much higher and stable in the Chinese market.

\section{Findings}

\section{NPD Approaches and Evolution}

In the four cases, three types of NPD approaches in MNCs were identified: multi-local, adaptation-based and platform-based. In the multi-local approach, a company has $R \& D$ centres in different areas of the world and each of them develops products for the local market. In the adaptation-based approach, the products are developed mainly in one location with only domestic market requirements considered in NPD projects, the products then being introduced later in other countries incorporating local adaptations. The platform-based approach is different from the above two in that the NPD projects are defined as global from the beginning, with requirements from all the countries taken into consideration. In NPD, the global (common) parts and local (special) parts are determined as early as possible. Table 2 shows a summary of three NPD approaches in MNCs.

The four cases show different patterns of evolution in NPD approaches (see Figure 1). Case 1 evolved from a multi-local approach to a platform-based approach. Case 2 changed from an adaptation-based approach to a platform-based approach. The two cases show a converging trend in NPD approaches. In contrast, Case 3 attempted to change from an adaptation-based towards a platform-based approach, but failed and then returned to the initial approach. Case 4 launched a global car as a sign of moving towards a platform-based approach. 
Table 2 NPD Approaches in MNCs

\begin{tabular}{|l|l|l|l|}
\hline NPD Approach & \multicolumn{1}{|c|}{ Definition } & \multicolumn{1}{c|}{ Advantages } & \multicolumn{1}{c|}{ Challenges } \\
\hline Multi-local & $\begin{array}{l}\text { R\&D units are located } \\
\text { in different countries } \\
\text { developing products for } \\
\text { local markets. }\end{array}$ & $\begin{array}{l}\text { Products are fully } \\
\text { tailored to local } \\
\text { customers. Developing } \\
\text { local products is less } \\
\text { complex. }\end{array}$ & $\begin{array}{l}\text { There is duplication in } \\
\text { product design. R\&D } \\
\text { costs are higher at the } \\
\text { global level. }\end{array}$ \\
\hline Adaptation-based & $\begin{array}{l}\text { Products are developed } \\
\text { for the domestic market } \\
\text { initially and are then } \\
\text { modified for sale in } \\
\text { other markets. }\end{array}$ & $\begin{array}{l}\text { There is less } \\
\text { duplication. NPD is less } \\
\text { complex as only local } \\
\text { requirements are } \\
\text { considered. }\end{array}$ & $\begin{array}{l}\text { Significant redesign } \\
\text { work is needed as } \\
\text { some requirements are } \\
\text { not considered } \\
\text { initially. }\end{array}$ \\
\hline Platform-based & $\begin{array}{l}\text { Different requirements } \\
\text { are considered in the } \\
\text { global NPD project. } \\
\text { Global and local parts } \\
\text { are determined in } \\
\text { projects. }\end{array}$ & $\begin{array}{l}\text { Economies of scale are } \\
\text { fully leveraged. The } \\
\text { different requirements } \\
\text { across countries are } \\
\text { fulfilled. More variety } \\
\text { can be generated based } \\
\text { on a common platform. }\end{array}$ & $\begin{array}{l}\text { Global projects are } \\
\text { more complex than } \\
\text { local projects to } \\
\text { manage. Specific } \\
\text { target markets must be } \\
\text { determined from the } \\
\text { beginning of platform } \\
\text { development. }\end{array}$ \\
\hline
\end{tabular}

Adaptation-based

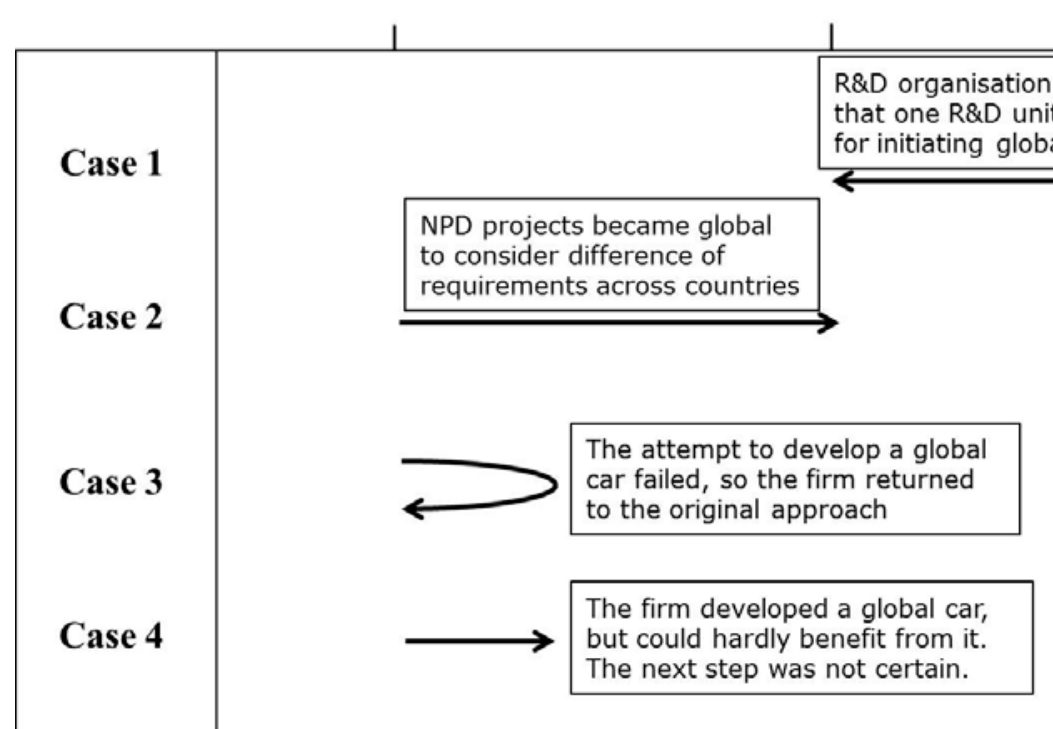

Multi-local

Fig. 1 NPD Approach: Evolution of Cases

The multi-local approach and the adaptation-based approach used to be common in the past in developed countries (Bartlett \& Ghoshal, 1998). Each has certain advantages and disadvantages. In the multi-local approach, R\&D centres are located 
close to the markets, and products are tailored to local customers in terms of aesthetic and functional requirements. NPD capability in multiple locations could be the result of a firm's growth by acquisition. However, with this approach, it is very difficult to share components as coordination is difficult across countries. As a result, duplication raises the R\&D costs. For example, the car chassis may be developed in totally different ways in different places, which can actually be avoided. When competition becomes more intense, the profitability of a company employing such a strategy will decline.

In the adaptation-based approach, NPD capability is usually centralised in one location. Different versions of products in different countries are derived from one basic design and therefore duplication is significantly lower. The adaptation of an existing product is much cheaper than developing a new product. However, with this approach, economies of scale are not fully realised. Although adaptation is usually intended to be minimal, mainly arising from differences in regulations and manufacturing equipment, the modifications often require the redesign of many interrelated components. Such modification is easier if requirements are considered early on in the NPD project (Gunzenhauser \& Bongulielmi, 2008, Halman, Hofer, \& van Vuuren, 2003). Also, due to specifications that are not easily modified (such as the size and appearance of the product), the products may not suit local customers' preferences.

The platform-based approach combines the advantages of the above two approaches and therefore denotes the trend in the NPD approach for MNCs. As parts are shared globally at significant levels, duplication is eliminated and economies of scale are fully realised. Also, as requirements from all over the world are considered early on in NPD projects, the products will be suitable for different markets. The products still have different versions in different countries, but by adopting a platform-based approach, it is clear which parts are global and which are local, so that no significant redesign is needed after product launch. Firms with a platform-based NPD approach can be more competitive in the global market by offering higher quality products at a lower price and still fulfilling local requirements. However, this 
approach is more complex to implement in practice. Firms have to determine the target markets (countries) at the beginning and handle a larger amount of information in product design, which can drive up the cost of a single project. Considering the challenges, such an approach may not be successfully implemented in every firm. We will elaborate this point next.

\section{The Motivation for Change towards a Platform-based Approach}

Change of NPD approaches takes significant effort and cost. For example, firms need to change organisational structures and NPD processes. Despite that, development of ICT tools and competition pressure lead to the motivation for change. For the platform-based NPD approach, a much larger amount of information is needed from local subsidiaries, including local requirements and feedback at different stages of projects. Such operations would not be desirable without the development and use of ICT tools. Two decades ago, when ICT tools were less developed and not as widely used as today, engineering and marketing personnel had to travel frequently to facilitate the flow of information needed for the platform-based approach, adding to the R\&D costs. Under such conditions, multi-local and adaptation-based approaches would be reasonable choices, as they do not need an intensive flow of information from all over the world.

Modern ICT tools, such as NPD process management software and teleconferencing systems, make cross-border communication much easier. For example, in the NPD process, engineers need to receive feedback from marketing personnel regarding whether products can meet local requirements. With teleconferencing systems, virtual meetings can be held globally in an efficient way. In addition, the documents of product design and market information can be transmitted easily through NPD process management software.

With more MNCs moving to a platform-based approach using ICT tools, firms that do not change (as in Case 2) will become less competitive over time. Many firms, by employing a platform-based approach, offer products of higher quality that meet 
local requirements at lower costs. As a result, unchanged firms will lose either market share or profit. Feeling the pressure of competition and survival, firms will seek to change towards a platform-based approach, even though firms will incur significant costs of organisational change.

\section{The Benefit of Change towards a Platform-based Approach}

However, benefiting from the platform-based approach has certain prerequisites. Therefore this approach may not be desirable for every firm. Cases 3 and 4 offer good examples for this. Unlike Cases 1 and 2, they lack strong brand awareness overseas and technical capability, hindering them from achieving sufficient market volume to yield the benefits of the more complex platform-based approach. In comparison, Cases 1 and 2 can benefit from platform-based approach due to their strong brand awareness and technical capability.

Brand awareness plays a vital role in car purchase as the brand is usually linked to safety for customers. Without a strong brand, the expected (average) sales volumes of cars are low. Though some cars can be popular in certain countries, as we found in the case studies, it is difficult to figure out at the beginning of NPD whether the market volume overseas worth the investment. There is a risk that after a global car is developed within a platform-based approach at a greater cost, it will not sell in overseas markets. Cases 3 and 4 illustrate this risk very well. Under such conditions, the benefits of the adaptation-based approach are very clear: after domestic product launch and overseas promotions, the company can choose the cars which have a higher success rate based on the market feedback. Any such prediction is more precise after domestic product launch and overseas promotions.

Technical capability is another factor contributing to the expected sales volumes. With low technical capability, the quality, functionality and aesthetics of a product will probably fall behind what competitors offer. Like in Cases 3 and 4, their cars fell behind competitor offerings in terms of fuel efficiency and the power of the engine, for instance, which made their cars unattractive even to customers who knew the 
brands or would like to consider cars with these brands.

\section{The Reinforcing Cycles}

Based on brand awareness and technical capability, MNCs are likely to be in a reinforcing cycle (virtuous or vicious) influencing the choice of an NPD approach (see Figure 2). Firms such as Case 1 and Case 2 have a high level of brand awareness and technical capability. When they start to develop a product, they expect the sales volume of the product to be high in their global markets. Therefore, with the use of ICT tools and competition pressure, they will adopt the platform-based approach to define a global car at the beginning of a project. Although developing a global car is more expensive, they can achieve economies of scale through high volume globally, so firms are willing to make such an investment. Knowing the requirements of all countries, the product can readily satisfy local customers at a low cost, which contributes to product competitiveness in the global market. Product competitiveness further contributes to the expected sales volume, therefore reinforcing the choice of the platform-based approach.

Firms with low brand awareness and technical capability, such as Cases 3 and 4, are in a vicious cycle. When they develop a product, they expect the overseas volume to be low. In fact, there are variations across products, but the average volume is low. Under such conditions, firms adopt an adaptation-based approach due to uncertain benefit from a platform-based approach which costs more. Another reason is that through an adaptation-based approach, they can focus on and better satisfy the domestic market, which has a higher market volume. However, in this approach, the product is less able to satisfy overseas markets, and has high incurred costs of product modification. This makes products less competitive in the overseas market. Uncompetitive products will reinforce the choice of the adaptation-based approach. This reinforcing cycle is likely to continue until the firms find a way of enhancing their technical capability and brand awareness to a significant extent. 

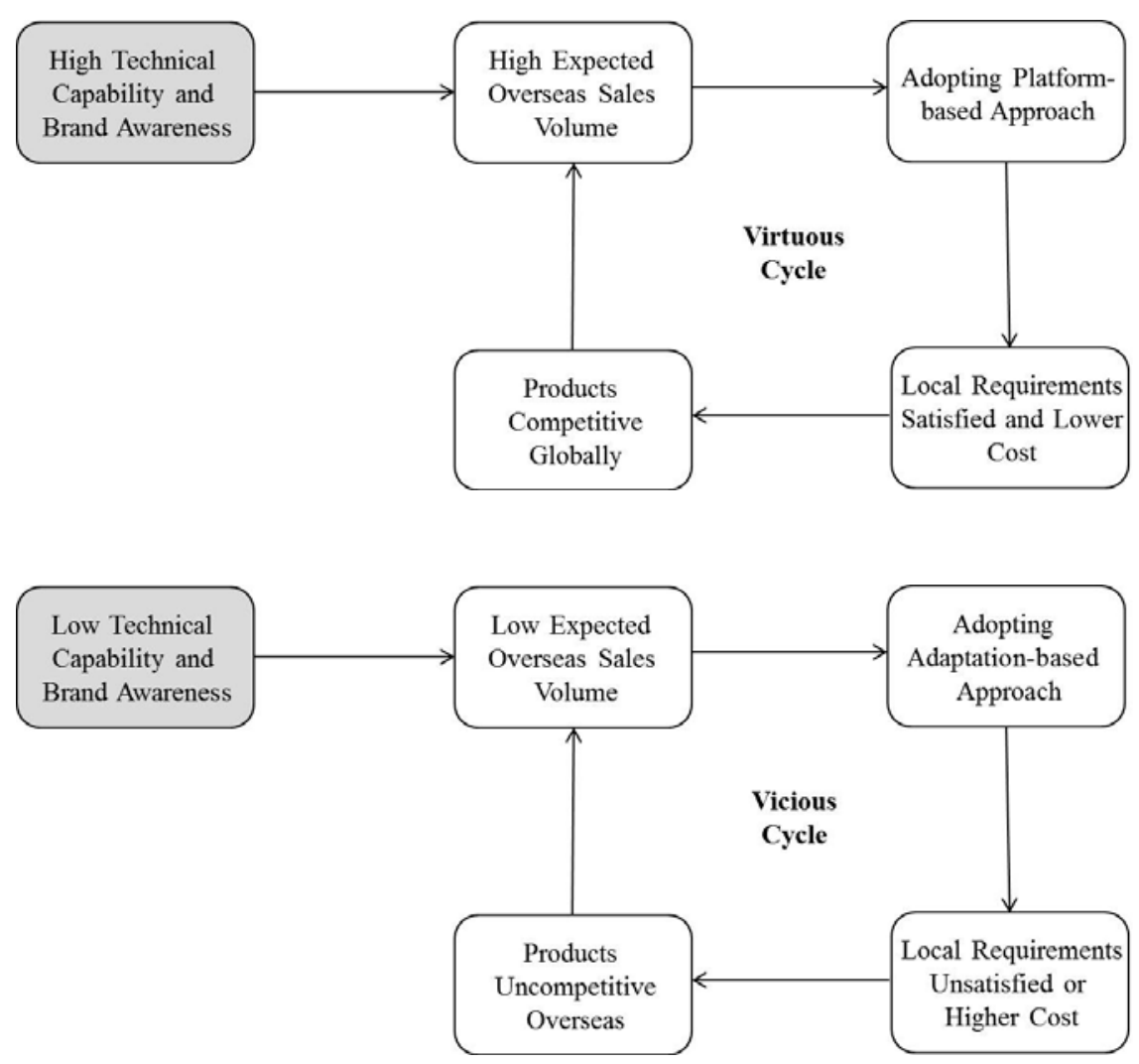

Fig. 2 Global NPD Approach and Competitiveness

\section{Discussion}

\section{Theoretical Contributions}

In this study, we bridge the areas of research in terms of international product strategy (standardisation/adaptation) and NPD in MNCs through proposing an NPD perspective on international product strategy. In prior studies, these two areas have largely been studied independently. By bridging the two areas, we contribute to the understanding of international product strategy, in particular how it is determined within the context of NPD.

Through a multiple-case study, we have identified three NPD approaches: multi-local, adaptation-based and platform-based. We have discussed their definitions, advantages and challenges. We show how NPD approaches can influence product forms regarding standardisation/adaptation. For example, for the adaptation-based approach, many components need to be redesigned as numerous requirements are not 
considered from the beginning. In the platform-based approach, much redesign work can be avoided as the requirements are considered from the beginning. Prior studies mainly addressed whether products need to be standardised/adapted (Calantone, Kim, Schmidt, \& Cavusgil, 2006, Katsikeas, Samiee, \& Theodosiou, 2006, Samiee \& Roth, 1992, Zou \& Cavusgil, 2002). However, our findings show how the products should be standardised/adapted in NPD for the global market, which has been discussed to a lesser extent in prior studies.

More importantly, we argue that certain factors could influence the choice of an NPD approach in MNCs. Prior studies identified the advantages of the platform-based approach (Chai, Wang, Song, Halman, \& Brombacher, 2012, Gunzenhauser \& Bongulielmi, 2008, Robertson \& Ulrich, 1998), which are confirmed in this study. However, prior studies have not addressed under what circumstances MNCs will choose this approach over others. In this study, we find the influencing factors including ICT development, competition pressure, brand awareness and technical capability. ICT development and competition pressure lead to the motivation for change towards a platform-based approach, which denotes the trend. Prior studies show that ICT tools make cross-border collaboration easier (Chang, 2006, Howells, 1995, Kleinschmidt, de Brentani, \& Salomo, 2010). We show that with the convenience of cross-border communication, manufacturers tend to change their NPD approaches under the competition pressure. Therefore, the competition pressure promotes the use of ICT tools. MNCs by adopting the platform-based NPD approach can be more competitive than those with the adaptation-based or multi-local approach.

Brand awareness and technical capability determine the benefit of the platform-based approach. Firms that have low technical capability and brand awareness are not likely to benefit from a platform-based approach due to their low expected market volume. As the literature shows that there is no single optimal position between standardisation and adaptation (Delene, Meloche, \& Hodskins, 1997, Katsikeas, Samiee, \& Theodosiou, 2006, Schmid \& Kotulla, 2011), this study suggests that the same applies to the choice of an NPD approach in MNCs. In this regard, we contribute to research on contingencies affecting the choice of NPD 
approaches (Pasche, Persson, \& Lofsten, 2011). In addition, we reveal the reinforcing cycles (virtuous or vicious) based on brand awareness and technical capability. This offers an additional explanation of case firms and highlights the role of the two factors.

\section{Limitations and Future Research}

As with all studies, this research has some limitations. In this study, only four case companies are examined, therefore, its generalisability needs further confirmation. In the future, more case companies could be studied to see if our findings could be replicated. Future studies could also test our findings through quantitative methods with a large sample. In addition, in this study we only explored the automotive industry. Future research could examine other manufacturing industries to see what findings can be generalised to other industries and what cannot. For example, brand awareness may be less important in some industries than in the automotive industry, which may influence the choice of the NPD approach. It will be important to identify key industrial factors that could influence the results.

Also, this study explores NPD as a whole without observing the role of relevant functions (e.g. R\&D, sourcing, production and marketing) involved in NPD. Future research could explore how these functions interact with each other in each NPD approach we have found. These functions may exert some influences on the evolution and the choice of the NPD approach. For example, the production function can be centralised globally or independent locally, which will influence NPD because manufacturing issues need to be taken into account during NPD. There is likely the co-evolution between each function and the NPD approach, which needs to be studied.

\section{Managerial Implications}

This study can draw implications for practices not only in the automotive industry, as focused on in this study, but also other manufacturing industries in which different 
requirements across countries remain. The platform-based NPD approach is superior in terms of global competition and therefore, firms should aim to move towards this approach in the long run. However, in the short term, such a path may not be suitable for every company depending on the current condition. Based on our case studies, there are certain paths that companies can follow to break the vicious cycle in relation to technical capability and brand awareness and be more competitive. The first path is acquisitions. Through acquisitions, the company can obtain stronger brands and advanced technologies, thus attaining a higher expected sales volume overseas. The NPD approach may be multi-local immediately after acquisition. The challenge is how to integrate R\&D centres to facilitate the platform-based approach. Change of power and processes of NPD is needed for integration. ICT tools should be used to support the platform-based approach which needs a large amount of information flows across countries. The second path is to gradually accumulate technical knowledge and brand awareness overseas. One tactic could be forming strategic alliances with leading manufacturers, which may be helpful for learning technologies and enhancing brand awareness overseas (Doz, 1996). For learning technologies, the firm could collaborate with the partner in NPD of cars. For enhancing brand awareness, the firm could advertise this alliance relationship whenever possible in overseas markets. In practice, a company can also mix the two paths in a flexible way in the growing process, for example accumulating technical knowledge through strategic alliances and the acquisition of brands.

\section{Appendix Interview Protocol}

\section{Company Background and Market Requirement}

- What are the product lines of the company?

- How are market requirements similar or different across countries?

- What is the market share?

- What are the target markets?

NPD Approaches Related to Product Standardisation/adaptation 
- How are products developed for different countries?

- How are products standardised/adapted for different requirements across countries?

- How are NPD activities organised across R\&D centres?

- Why are NPD activities organised this way?

\section{Change of NPD Approaches and Influencing Factors}

- How were the NPD approach changed over the years?

- What is the story behind the change?

- Was the change successful?

- If the old approach could not work well, why?

\section{References}

Andriopoulos, C., \& Lewis, M. W. 2009. Exploitation-exploration tensions and organizational ambidexterity: Managing paradoxes of innovation. Organization Science, 20(4): 696-717.

Bélanger, J., Berggren, C., Björkman, T., \& Köhler, C. 1999. Being local worldwide: $A b b$ and the challenge of global management. Ithaca, N.Y.: Cornell University Press.

Barczak, G., \& McDonough, E. F. 2003. Leading global product development teams. Research-Technology Management, 46(6): 14-18.

Bartlett, C. A., \& Ghoshal, S. 1998. Managing across borders: The transnational solution. 2nd ed. Boston, Mass.: Harvard Business School Press.

Bartlett, C. A., \& Ghoshal, S. 2000. Transnational management: Text, cases, and readings in cross-border management. 3rd ed. Boston: Irwin McGraw-Hill.

Bessant, J., \& Francis, D. 1997. Implementing the new product development process. Technovation, 17(4): 189-197.

Bierly III, P. E., Stark, E. M., \& Kessler, E. H. 2009. The moderating effects of virtuality on the antecedents and outcome of NPD team trust. Journal of Product Innovation Management, 26(5): 551-565.

Bloch, P. H. 1995. Seeking the ideal form: Product design and consumer response. Journal of Marketing, 59(3): 16-29.

Bohnsack, R., Pinkse, J., \& Kolk, A. 2014. Business models for sustainable technologies: Exploring business model evolution in the case of electric vehicles. Research Policy, 43(2): 284-300.

Calantone, R. J., Cavusgil, S. T., Schmidt, J. B., \& Shin, G.-C. 2004. Internationalization and the dynamics of product adaptation - an empirical investigation. Journal of Product Innovation Management, 21(3): 185-198. 
Calantone, R. J., Kim, D., Schmidt, J. B., \& Cavusgil, S. T. 2006. The influence of internal and external firm factors on international product adaptation strategy and export performance: A three-country comparison. Journal of Business Research, 59(2): 176-185.

Cavusgil, S. T., \& Zou, S. 1994. Marketing strategy-performance relationship: An investigation of the empirical link in export market ventures. Journal of Marketing, 58(1): 1-21.

Cavusgil, S. T., Zou, S., \& Naidu, G. M. 1993. Product and promotion adaptation in export ventures: An empirical investigation. Journal of International Business Studies, 24(3): 479-506.

Chai, K. H., Wang, Q., Song, M., Halman, J. I. M., \& Brombacher, A. C. 2012. Understanding competencies in platform-based product development: Antecedents and outcomes. Journal of product innovation management, 29(3): 452-472.

Chang, C. M. 2006. Web-based tools for product development. International Journal of Product Development, 3(2): 167-180.

Cooper, R. G. 1994. Third-generation new product processes. Journal of Product Innovation Management, 11(1): 3-14.

Cooper, R. G., \& Kleinschmidt, E. J. 1985. The impact of export strategy on export sales performance. Journal of International Business Studies, 16(1): 37-55.

De Brentani, U., \& Kleinschmidt, E. J. 2004. Corporate culture and commitment: Impact on performance of international new product development programs. Journal of Product Innovation Management, 21(5): 309-333.

De Brentani, U., Kleinschmidt, E. J., \& Salomo, S. 2010. Success in global new product development: Impact of strategy and the behavioral environment of the firm. Journal of Product Innovation Management, 27(2): 143-160.

Delene, L. M., Meloche, M. S., \& Hodskins, J. S. 1997. International product strategy: Building the standardisation-modification decision. Irish Marketing Review, 10(1): 47-54.

Doz, Y. L. 1996. The evolution of cooperation in strategic alliances: Initial conditions or learning processes? Strategic Management Journal, 17(S1): 55-83.

Eisenhardt, K. M. 1989. Building theories from case study research. Academy of Management Review, 14(4): 532-550.

Eisenhardt, K. M., \& Graebner, M. E. 2007. Theory building from cases: Opportunities and challenges. Academy of Management Journal, 50(1): 25-32.

Eppinger, S. D., \& Chitkara, A. R. 2006. The new practice of global product development. MIT Sloan Management Review, 47(4): 22-30.

Eslami, M. H., \& Lakemond, N. 2016. Internal integration in complex collaborative product development projects. International Journal of Innovation Management, 20(1).

Gooderham, P. 2012. The transition from a multi-domestic to globally integrated multinational enterprise-in an industry where local taste matters. European Journal of International Management, 6(2): 175-198.

Graber, D. R. 1996. How to manage a global product development process. Industrial 
Marketing Management, 25(6): 483-489.

Griffin, A., \& Hauser, J. R. 1993. The voice of the customer. Marketing Science, 12(1): $1-27$.

Gunzenhauser, M., \& Bongulielmi, L. 2008. A value chain oriented approach for the development of global platforms in the systems business. Journal of Engineering Design, 19(6): 465-487.

Halman, J. I., Hofer, A. P., \& van Vuuren, W. 2003. Platform-driven development of product families: Linking theory with practice. Journal of Product Innovation Management, 20(2): 149-162.

Hansen, Z. N. L., \& Ahmed-Kristensen, S. 2011. Global product development: The impact on the product development process and how companies deal with it. International Journal of Product Development, 15(4): 205-226.

Hart, S., Jan Hultink, E., Tzokas, N., \& Commandeur, H. R. 2003. Industrial companies' evaluation criteria in new product development gates. Journal of Product Innovation Management, 20(1): 22-36.

Hauser, J., Tellis, G. J., \& Griffin, A. 2006. Research on innovation: A review and agenda for marketing science. Marketing Science, 25(6): 687-717.

Howells, J. R. 1995. Going global: The use of ICT networks in research and development. Research Policy, 24(2): 169-184.

Jarvenpaa, S. L., \& Leidner, D. E. 1999. Communication and trust in global virtual teams. Organization Science, 10(6): 791-815.

Katsikeas, C. S., Samiee, S., \& Theodosiou, M. 2006. Strategy fit and performance consequences of international marketing standardization. Strategic Management Journal, 27(9): 867-890.

Kim, J., \& Wilemon, D. 2002. Focusing the fuzzy front-end in new product development. R\&D Management, 32(4): 269-279.

Kleinschmidt, E., de Brentani, U., \& Salomo, S. 2010. Information processing and firm-internal environment contingencies: Performance impact on global new product development. Creativity \& Innovation Management, 19(3): 200-218.

Kleinschmidt, E. J., de Brentani, U., \& Salomo, S. 2007. Performance of global new product development programs: A resource-based view. Journal of Product Innovation Management, 24(5): 419-441.

Kotabe, M. 1990. Corporate product policy and innovative behavior of European and Japanese multinationals: An empirical investigation. Journal of Marketing, 54(2): 19-33.

Kotler, P. 1986. Global standardization - courting danger. Journal of Consumer Marketing, 3(2): 13-15.

Lawrence, T. B., \& Dover, G. 2015. Place and institutional work: Creating housing for the hard-to-house. Administrative Science Quarterly, 60(3): 371-410.

Leonidou, L. C., Katsikeas, C. S., \& Samiee, S. 2002. Marketing strategy determinants of export performance: A meta-analysis. Journal of Business Research, 55(1): 51-67.

Levitt, T. 1983. The globalization of markets. Harvard Business Review, 61(3): 92-102. 
Luchs, M., \& Swan, K. S. 2011. The emergence of product design as a field of marketing inquiry. Journal of Product Innovation Management, 28(3): 327-345.

McDonough III, E. F., Kahn, K. B., \& Barczak, G. 2001. An investigation of the use of global, virtual, and colocated new product development teams. Journal of Product Innovation Management, 18(2): 110-120.

Millson, M. R., \& Kim, J. 2015. A moderation study of organisational integration and NPD process proficiency in the us and Korean heavy construction equipment industries. International Journal of Innovation Management, 19(5).

Moorman, C., \& Miner, A. S. 1998. The convergence of planning and execution: Improvisation in new product development. Journal of Marketing, 62(3): 1-20.

Muffatto, M. 1999. Platform strategies in international new product development. International Journal of Operations \& Production Management, 19(5/6): 449-459.

Nambisan, S. 2003. Information systems as a reference discipline for new product development. MIS Quarterly, 27(1): 1-18.

Ozer, M. 2000. Information technology and new product development: Opportunities and pitfalls. Industrial Marketing Management, 29(5): 387-396.

Pasche, M., Persson, M., \& Lofsten, H. 2011. Effects of platforms on new product development projects. International Journal of Operations \& Production Management, 31(11): 1144-1163.

Robertson, D., \& Ulrich, K. 1998. Planning for product platforms. Sloan Management Review, 39(4): 19-31.

Rugman, A., \& Hodgetts, R. 2001. The end of global strategy. European Management Journal, 19(4): 333-343.

Söderquist, K. E. 2006. Organising knowledge management and dissemination in new product development: Lessons from 12 global corporations. Long Range Planning, 39(5): 497-523.

Salomo, S., Kleinschmidt, E. J., \& de Brentani, U. 2010. Managing new product development teams in a globally dispersed NPD program. Journal of Product Innovation Management, 27(7): 955-971.

Samiee, S., \& Roth, K. 1992. The influence of global marketing standardization on performance. Journal of Marketing, 56(2): 1-17.

Schmid, S., \& Kotulla, T. 2011. 50 years of research on international standardization and adaptation - from a systematic literature analysis to a theoretical framework. International Business Review, 20(5): 491-507.

Schmidt, J. B., \& Calantone, R. J. 2002. Escalation of commitment during new product development. Journal of the Academy of Marketing Science, 30(2): 103-118.

Seidel, V. P. 2007. Concept shifting and the radical product development process. Journal of Product Innovation Management, 24(6): 522-533.

Shibata, T., \& Kodama, M. 2015. Managing the change of strategy from customisation to product platform: Case of Mabuchi motors, a leading dc motor manufacturer. International Journal of Technology Management, 67(2-4): 289-305. 
Subramaniam, M. 2006. Integrating cross-border knowledge for transnational new product development. Journal of Product Innovation Management, 23(6): 541-555.

Subramaniam, M., \& Venkatraman, N. 2001. Determinants of transnational new product development capability: Testing the influence of transferring and deploying tacit overseas knowledge. Strategic Management Journal, 22(4): 359-378.

Tavcar, J., Zavbi, R., Verlinden, J., \& Duhovnik, J. 2005. Skills for effective communication and work in global product development teams. Journal of Engineering Design, 16(6): 557-576.

Trappey, C. V., Trappey, A. J. C., Tzu-An, C., \& Jen-Yau, K. 2009. A strategic product portfolio management methodology considering $R \& D$ resource constraints for engineering-to-order industries. International Journal of Technology Management, 48(2): 258-276.

Tzokas, N., Hultink, E. J., \& Hart, S. 2004. Navigating the new product development process. Industrial Marketing Management, 33(7): 619-626.

Ulrich, K. 1995. The role of product architecture in the manufacturing firm. Research Policy, 24(3): 419-440.

Ulrich, K. T., \& Eppinger, S. D. 2012. Product design and development. 5th ed. New York: McGraw-Hill.

Verworn, B. 2006. How german measurement and control firms integrate market and technological knowledge into the front end of new product development. International Journal of Technology Management, 34(3/4): 379-389.

Wheelwright, S. C., \& Clark, K. B. 1992. Revolutionizing product development: Quantum leaps in speed, efficiency, and quality. New York: The Free Press.

Yin, R. K. 2009. Case study research: Design and methods. 4th ed. Los Angeles, CA: Sage.

Yip, G. S. 2003. Total global strateg II: Updated for the internet and service era. Upper Saddle River, N.J.: Pearson Education International.

Zou, S., \& Cavusgil, S. T. 2002. The GMS: A broad conceptualization of global marketing strategy and its effect on firm performance. Journal of Marketing, 66(4): 40-56. 